\title{
Year-Round Performance of a Passive Sulfate-Reducing Bioreactor that Uses Rice Bran as an Organic Carbon Source to Treat Acid Mine Drainage
}

\author{
Yuki Sato $^{1} \cdot$ Takaya Hamai $^{1} \cdot$ Tomoyuki Hori $^{2} \cdot$ Hiroshi Habe $^{2} \cdot$ Mikio Kobayashi $^{3}$ • \\ Takeshi Sakata ${ }^{3}$
}

Received: 15 February 2017 / Accepted: 28 August 2017 / Published online: 2 September 2017

(c) The Author(s) 2017. This article is an open access publication

\begin{abstract}
The development of compact and cost-effective passive treatment systems is of critical importance for acid mine drainage (AMD) remediation in Japan. The purpose of this study was to construct an AMD treatment system comprising a sulfate-reducing bioreactor using rice bran as a carbon source for sulfate-reducing bacteria (SRB) and to demonstrate its stable operation for at least a year in terms of continuous sulfate reduction and metal removal. Our $35 \mathrm{~L}$ bioreactor comprised a packed inoculum layer of a mixture of rice husks, limestone, and field soil, which was covered with rice bran. During operation, the AMD input flow rate was adjusted to $11.7 \mathrm{~mL} / \mathrm{min}$ (hydraulic retention time, HRT; $50 \mathrm{~h}$ ). Throughout the year, physicochemical analyses of system input and output AMD samples revealed that both $\mathrm{pH}$ and oxidation-reduction potential values were consistent with the process of sulfate reduction by SRB, although this reduction was observed to be stronger in summer than in winter. Efficient metal removal was observed,
\end{abstract}

Electronic supplementary material The online version of this article (doi:10.1007/s10230-017-0489-6) contains supplementary material, which is available to authorized users.

Takaya Hamai

hamai-takaya@jogmec.go.jp

Yuki Sato

sato-yuki@jogmec.go.jp

1 Metals Technology Center, Japan Oil, Gas and Metals National Corporation (JOGMEC), 9-3 Furudate, Kosaka-kozan, Kosaka, Akita 017-0202, Japan

2 Environmental Management Research Institute, National Institute of Advanced Industrial Science and Technology (AIST), 16-1 Onogawa, Tsukuba, Ibaraki 305-8569, Japan

3 Japan Oil, Gas and Metals National Corporation (JOGMEC), 2-10-1 Toranomon, Minato-ku, Tokyo 105-0001, Japan with concentrations at the outlet port of $<0.33 \mathrm{mg} / \mathrm{L} \mathrm{Zn}$, $<0.08 \mathrm{mg} / \mathrm{L} \mathrm{Cu}$, and $<0.005 \mathrm{mg} / \mathrm{L} \mathrm{Cd}$, more than meeting Japan's national effluent standards. Illumina sequencing of 16S rRNA genes revealed that Desulfatirhabdium butyrativorans-related species, which belong to a lineage within Deltaproteobacteria, were dominant (39-48\% of the total SRB population) within the bioreactor.

Keywords Passive treatment - Sulfate-reducing bacteria . Metal removal · Reutilization of agricultural waste .

On-site demonstration

\section{Introduction}

Acid mine drainage (AMD) from metal and coal mines is a significant environmental concern if it is discharged untreated into rivers (Colmer and Hinkle 1947; Price and Errington 1998). Therefore, many treatment methods have been used to neutralize and remove harmful metals from AMD (Rakotonimaro et al. 2016).

In Japan, there are many abandoned mine sites where metal-containing AMD occurs. Municipalities, governments, and companies that hold mining rights are responsible for treating these effluents. The business of AMD treatment is non-profit; therefore, cost savings are required where possible. Most AMD treatment methods at mine sites in Japan have used active treatment processes with chemical reagents, e.g. neutralization and sedimentation, because such approaches can shorten the processing time and are easily controllable. However, active treatment processes bear significant costs to cover the continuous maintenance of facilities, the addition of alkalinity, and the input of manpower. Indeed, in Japan, the treatment of AMD effluents costs $\approx \$ 37.8$ million per year (Mine Safety and Explosives Control Division, METI, Japan 2013). 
By contrast, passive and semi-passive treatment processes are less expensive and have less maintenance demands. One sustainable approach for removing metals from AMD is the use of biochemical reactors (bioreactors). Bioreactors with sulfate-reducing bacteria (SRB) offer particular advantages, such as the production of a compact sludge, low operation costs, and minimal maintenance costs (Gusek et al. 1998). In certain countries other than Japan, full-scale passive treatment facilities using SRB have been introduced. These typically have very large surface areas, allowing a long hydraulic retention time (HRT; Nairn et al. 2010; The ITRC Biochemical Reactors for Mining-Influenced Waste Team 2013). However, it is difficult to build large facilities for passive AMD treatment in Japan because many mine sites are located in steep mountainous areas. Therefore, to be used in Japan, compaction and optimization of the processes with reduced HRT is necessary.

Japan Oil, Gas and Metals National Corporation (JOGMEC) has been developing a compact passive treatment process with a vertical flow bioreactor that contains SRB (Hamai et al. 2016). Since the concentration of dissolved organic carbon in AMD is very low (chemical oxygen demand is usually less than $10 \mathrm{mg} / \mathrm{L}$ of $\mathrm{O}_{2}$; Kolmert and Johnson 2001), a carbon source must be added to the bioreactor to promote $\mathrm{SRB}$ activity. To reduce operation costs, organic wastes such as animal manure, saw dust, wood chips, rice straw, and corn husks have been used as carbon sources for SRB (Chang et al. 2000; Gibert et al. 2004; Hiibel et al. 2011; McCullough and Lund 2011; Neculita et al. 2007, 2011; Zagury et al. 2006; Zhang and Wang 2014). Among such organic wastes, rice bran, which contains starches, lipids, proteins, and other polysaccharides, is thought to be easily degraded to simple carbon substrates with low molecular weights that are suitable for SRB utilization. Therefore, JOGMEC is assessing the novel application of rice bran as a source of microbial carbon and nitrogen in bioreactors.

In the present study, a passive sulfate-reducing bioreactor using rice bran and rice husks (JOGMEC process) was operated for a year. Water quality within the bioreactor (temperature, $\mathrm{pH}$, oxidation-reduction potential (ORP), and sulfate, sulfide, and metal concentrations) were continually monitored. Additionally, the SRB community present at around $5{ }^{\circ} \mathrm{C}$, the lowest AMD temperature observed in this study, was analyzed by Illumina sequencing.

\section{Materials and Methods}

\section{Acid Mine Drainage (AMD) and Iron Removal}

The raw AMD ( $\mathrm{pH}$ 3.5) used in this study contained approximately $40 \mathrm{mg} / \mathrm{L} \mathrm{Fe}$ (as ferrous iron), $15 \mathrm{mg} / \mathrm{L} \mathrm{Zn,}$ $5 \mathrm{mg} / \mathrm{L} \mathrm{Cu}$, and $0.06 \mathrm{mg} / \mathrm{L} \mathrm{Cd}$, as well as $300 \mathrm{mg} / \mathrm{L}$ of sulfate. The AMD was initially passed through an ironoxidation removal reactor, which reduced the iron concentration to $<5 \mathrm{mg} / \mathrm{L}$ ( $\mathrm{pH} 3.0$ ). The reactor discharge was then fed into a sulfate-reducing bioreactor using an electric pump (Fig. 1).

\section{Passive Sulfate-Reducing Bioreactor}

The reactor was constructed using a polyvinyl chloride column (1100 mm height $\times 250 \mathrm{~mm}$ diameter; Fig. 1$)$ in a prefabricated laboratory at an abandoned mine site. The raw AMD flowed into the reactor through an inlet port at the top of the column, and the treated AMD flowed through an outlet at the base. The reactor had four ports that allowed for sampling of the AMD at different column heights (every $250 \mathrm{~mm}$ from the bottom; Fig. 1). The column was first packed with an inoculum mixture of $4.5 \mathrm{~kg}$ of rice husks, $18 \mathrm{~kg}$ of limestone (3-20 $\mathrm{mm}$ in particle diameter), and $17.5 \mathrm{~g}$ of field soil in a layer of approximately $1000 \mathrm{~mm}$. Then, $1.5 \mathrm{~kg}$ of rice bran was placed on top of this layer before the column was sealed and subsequently saturated with approximately $35 \mathrm{~L}$ of AMD, which flowed through the reactor at a prescribed HRT. This passive AMD treatment system, using a sulfate-reducing bioreactor consisting of rice bran and rice husks, was termed the "JOGMEC process." The input flow rate was adjusted to $11.7 \mathrm{~mL} / \mathrm{min}$ (HRT: $50 \mathrm{~h}$ ) using an EHN-B11 VHMR electric pump (IWAKI).

\section{Sampling and Chemical Analyses of Treated AMD from the Bioreactor}

The experiment was initiated in September 2013 and sampling continued until the end of January 2015. Water

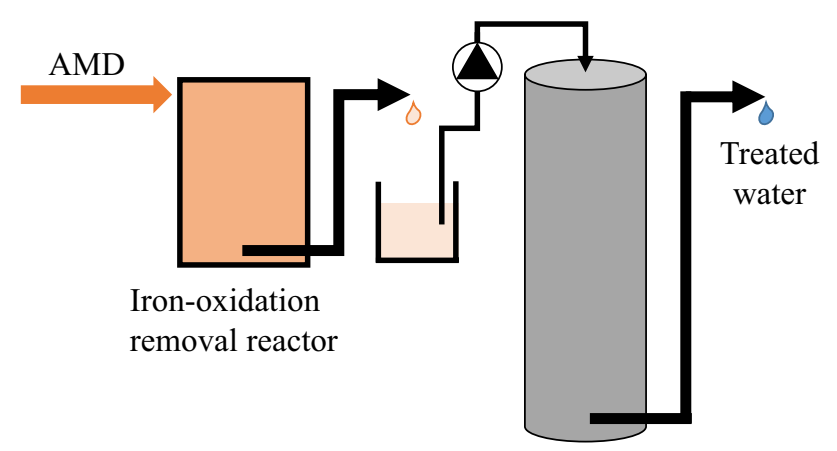

Sulfate-reducing bioreactor

Fig. 1 Treatment flow of the JOGMEC process. The raw AMD ferrous ion concentration of $40 \mathrm{mg} / \mathrm{L}$ was reduced to $<5 \mathrm{mg} / \mathrm{L}$ by a pretreatment process in an iron-oxidation removal reactor; the $\mathrm{pH}$ value was also decreased to around 3.0 from 3.5. Pre-treated AMD was then fed into the sulfate-reducing bioreactor using an electric pump 
from the reactor was sampled from one to several times per week at the inlet port, outlet port, and four sampling ports (ports 1-4 in Fig. 2). The sulfate ion concentration in the sample water was analyzed using a Dionex ICS2100 ion chromatography system with a Dionex IonPac AS22 column (Thermo Scientific). The pH, ORP, and temperature were measured using a LAQUA act D-73 pH/ Ion meter (HORIBA Scientific). For metal ion concentration analysis, $25 \mathrm{~mL}$ of sample was desiccated on a heated sand bath after the addition of $1 \mathrm{~mL}$ of nitric acid and $50 \mu \mathrm{L}$ of $60 \mathrm{wt} \%$ of perchloric acid to break down any organic matter. The dried sample was then dissolved in $185 \mu \mathrm{L}$ of nitric acid and diluted to $25 \mathrm{~mL}$. The $\mathrm{Zn}, \mathrm{Cu}$, and $\mathrm{Cd}$ concentrations were determined using an SPS3100 plasma spectrometer (SII Nano Technology) according to the "General Rules for Atomic Emission Spectrometry" (JIS K 0116:2014). Monitoring of the $\mathrm{Zn}$ and Cu concentrations in the bioreactor water samples was initiated in September 2013 (at start-up), whereas for Cd it was started in March 2014.

\section{SRB Community Analysis by Illumina Sequencing}

Samples for microbial community analyses were obtained from the bottom (sampling Port 4) of the sulfate-reducing bioreactor in January 2015 (day 492). DNA extraction,

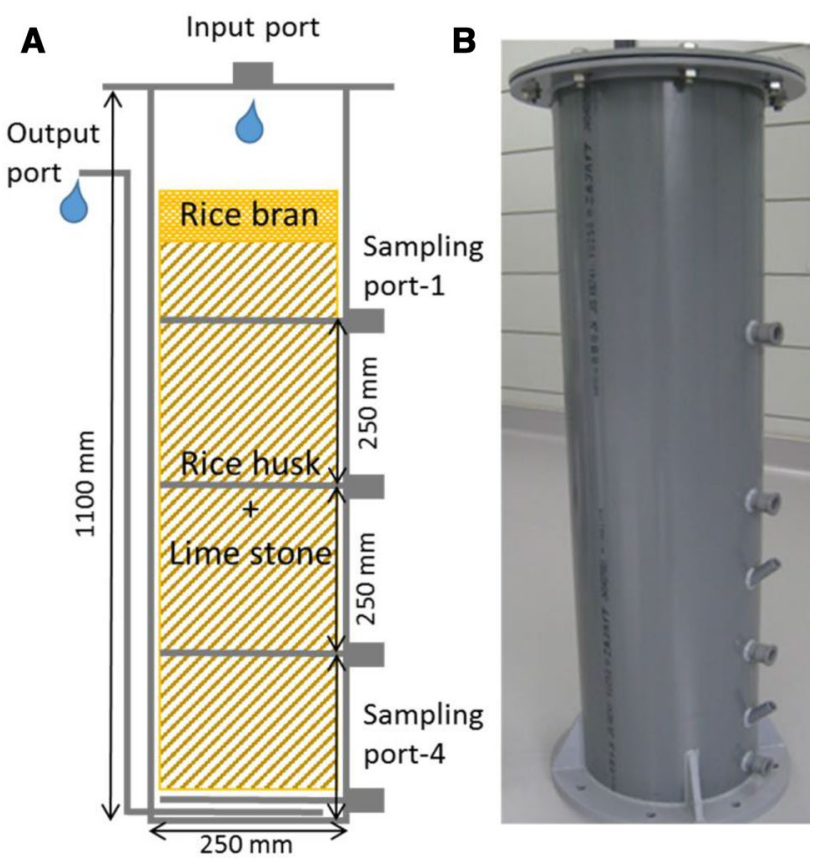

Fig. 2 Conceptual diagram (a) and appearance (b) of a vertical flow sulfate-reducing bioreactor that uses rice bran and rice husks to treat acid mine drainage [Japan Oil, Gas and Metals National Corporation (JOGMEC) process]. The bioreactor was set up in a prefabricated laboratory and covered in insulation material. The laboratory temperature was not artificially controlled
16S rRNA gene amplification, Illumina sequencing, and sequence data analyses were carried out by Nippon Steel \& Sumikin Eco-Tech. Briefly, DNA was extracted from the samples using the ISOIL for beads beating kit (Nippon Gene), quantified using the PicoGreen dsDNA assay kit (Invitrogen), and used as a template for polymerase chain reaction (PCR) amplification. The V4-V5 region of $16 \mathrm{~S}$ rRNA genes was amplified using the primers U515F (sequence: GTGYCAGCMGCCGCGGTA) and 926R (sequence: CCGYCAATTCMTTTRAGTT). Appropriate amounts of the 16S rRNA gene segments were subjected to paired-end sequencing with a MiSeq sequencer (Illumina). Removal of low-quality and chimeric sequences, as well as operational taxonomic unit (OTU) grouping (97\% sequence identity cut-off), were performed using the QIIME software package (Caporaso et al. 2010). Representative sequences for each OTU were assigned using the Greengene (DeSantis et al. 2006) and SILVA software packages (http://www. arb-silva.de/projects/living-tree/). A phylogenetic tree diagram of the SRB identified in this study was drawn based on the neighbor-joining method (Saitou and Nei 1987) using MEGA7 software (ver. 7.0.18; Kumar et al. 2016). Evolutionary distances were computed using the maximum composite likelihood method (Tamura et al. 2004).

\section{Results and Discussion}

\section{Seasonal Changes in Temperature, $\mathrm{pH}$, and ORP}

The location of the experimental site was in northern Japan. The average temperature in the prefabricated laboratory during the summer season (May-October) was $18.8^{\circ} \mathrm{C}$, whereas in the winter (November-April), it was $5.6^{\circ} \mathrm{C}$. The temperature of the raw AMD was relatively stable between 10 and $16{ }^{\circ} \mathrm{C}\left(12.9^{\circ} \mathrm{C}\right.$ average) throughout the year (Fig. 3a). However, as the laboratory room temperature was not controlled, the temperature of the AMD within the column at times fell below $10{ }^{\circ} \mathrm{C}$ in winter (for example, in mid-November 2013). The lowest temperature recorded was approximately $5{ }^{\circ} \mathrm{C}$ from January to February 2014 (Fig. 3a).

Regarding the $\mathrm{pH}$ of the AMD in the bioreactor (originally $\mathrm{pH} 3.5$ ), an increasing tendency was observed over time (Fig. 3b). Initial neutralization of the AMD occurred in the bioreactor due to the limestone. As a result, the $\mathrm{pH}$ increased to the optimum range (5.0-9.0) for SRB activity (Postgate 1984). The $\mathrm{pH}$ of the sampled water subsequently remained unchanged at around 7.0 throughout the remainder of the year (except at Port 1, which was located nearest to the bioreactor inlet [Fig. 2] and so was subject to only a short interaction period with the limestone). Until mid-November 2013, the $\mathrm{pH}$ of water from Port 1 continued to decrease until it was $\approx 5.0$; this $\mathrm{pH}$ was maintained from January 


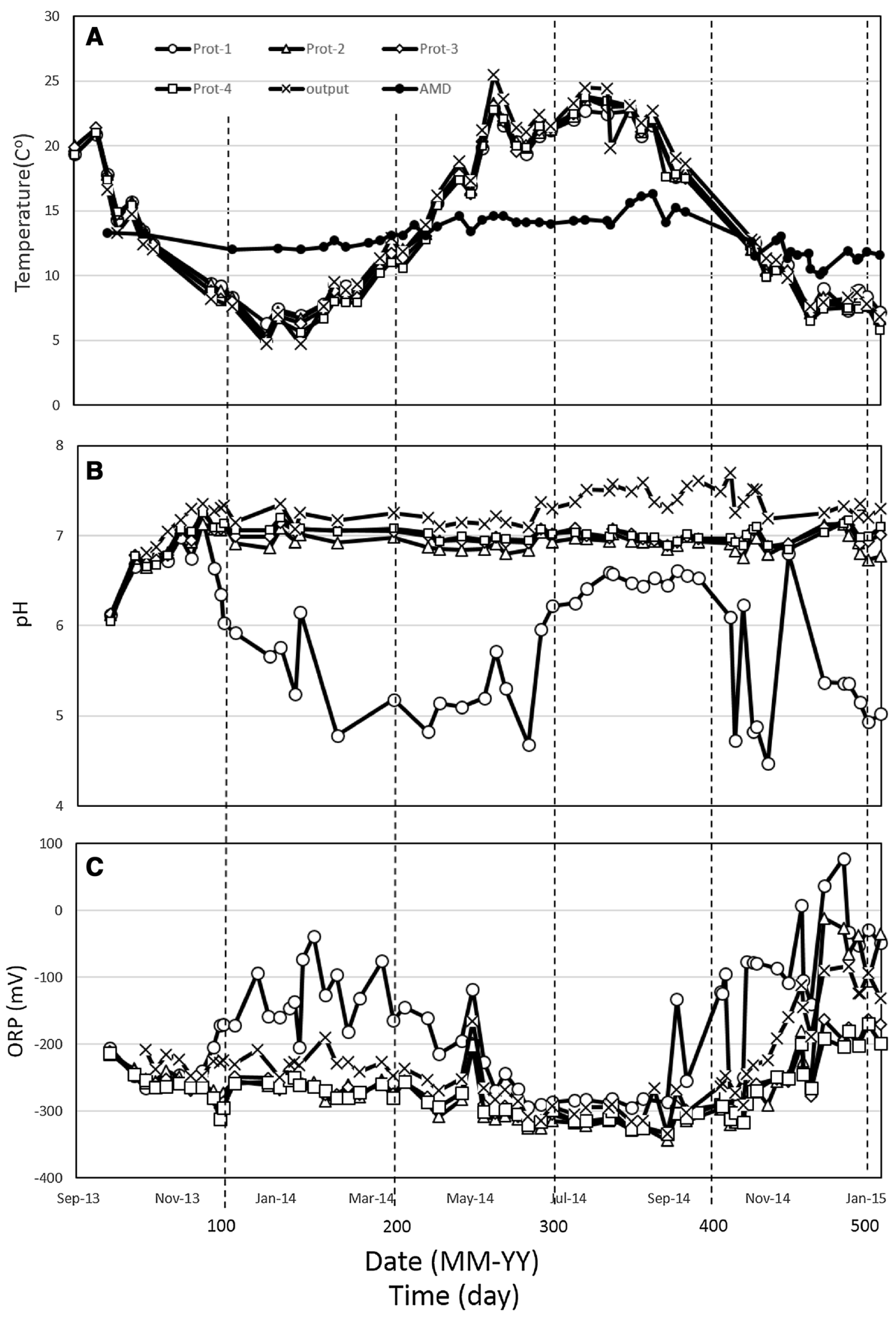


\Fig. 3 Seasonal changes in temperature (a), $\mathrm{pH}(\mathbf{b})$, and oxidationreduction potential (ORP) (c) in the sulfate-reducing bioreactor from September 2013 to January 2015. Symbols: open circle Port 1, open triangle Port 2, open diamond Port 3, open square Port 4, cross outlet, closed circle acid mine drainage (AMD)

to May 2014. Subsequently, the $\mathrm{pH}$ of the sampled water increased to around $\mathrm{pH} 6.5$ at Port 1 , before decreasing again in October 2014 (Fig. 3b). Bacterial dissimilatory reduction of the sulfate ion to the sulfide ion generates alkalinity (as the hydrogen carbonate ion), as indicated in Formula [1]. In other words, it is believed that the SRB provided $\mathrm{pH}$ buffering. As SRB in the bioreactor actively catalyzed sulfate ion reduction, especially during the summer, system pH increased (Fig. 3b).

ORP values favorable for SRB (less than $-100 \mathrm{mV}$; Postgate 1984) were achieved in the bioreactor throughout the year (Fig. 3c). Even more suitable ORP values of $-300 \mathrm{mV}$ (Prasad et al. 1999) were achieved during the summer, and in most cases, bioreactor ORP values did not rise above $-200 \mathrm{mV}$, except at Port 1, where it ranged from -240 to -39 mV from mid-November 2013 to April 2014, and from -274 to $+77 \mathrm{mV}$ from October 2014 to January 2015. The decrease in ORP during the summer season was probably due to oxygen consumption associated with the microbial degradation of the rice bran. Overall, both $\mathrm{pH}$ and ORP were favorable for bioreactor SRB.

\section{Variations in Sulfate Reduction and Sulfide Generation Over Time}

Initial sulfate ion concentrations at the inlet port ranged from 245 to $380 \mathrm{mg} / \mathrm{L}$ (average $300 \mathrm{mg} / \mathrm{L}$ ). As shown in Fig. 4a, sulfate reduction was observed even in the uppermost

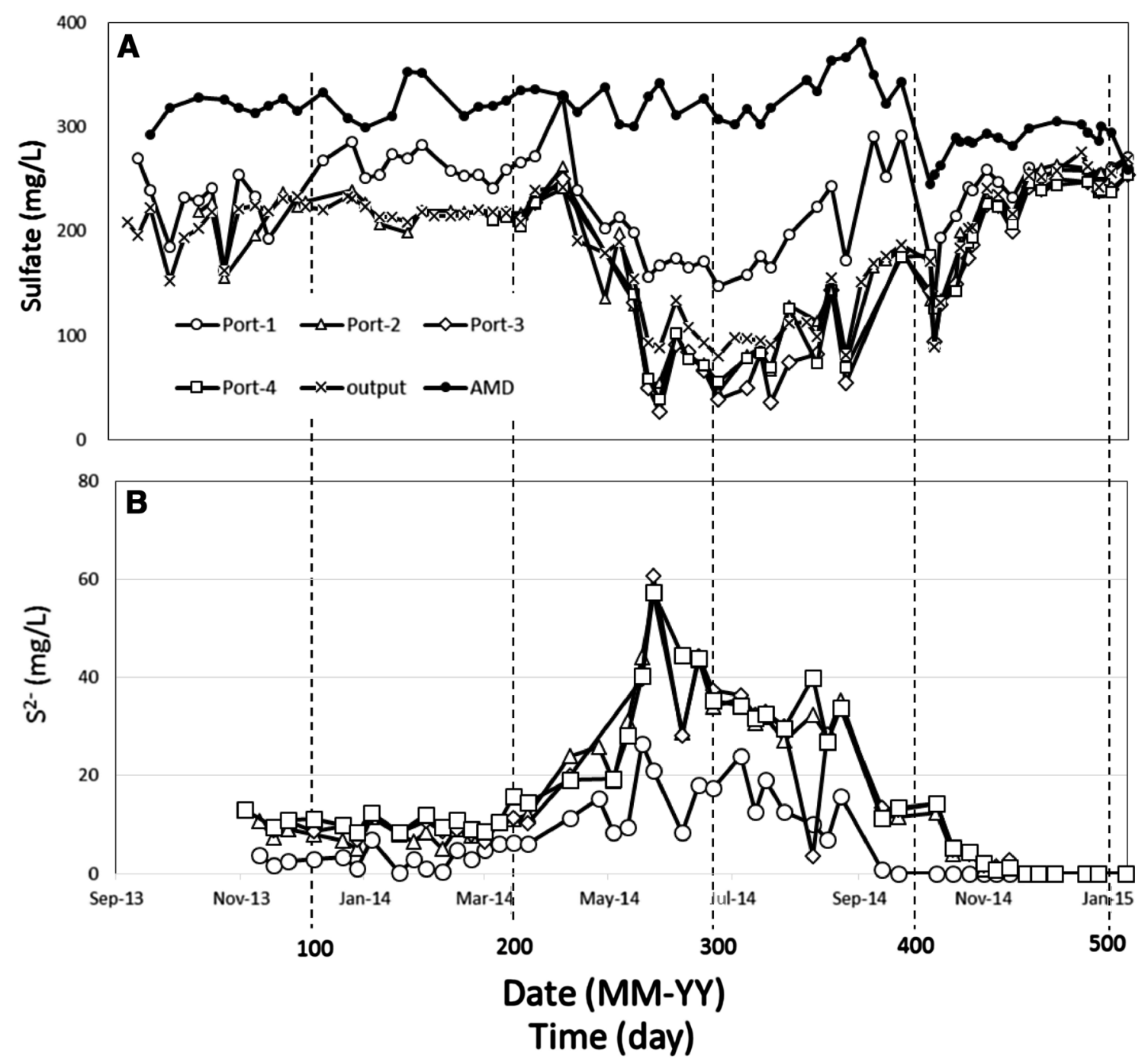

Fig. 4 Sulfate ion (a) and sulfide ion (b) concentrations in the sulfate-reducing bioreactor from September 2013 to January 2015 . Symbols: open circle Port 1, open triangle Port 2, open diamond Port 3, open square Port 4, closed circle AMD 


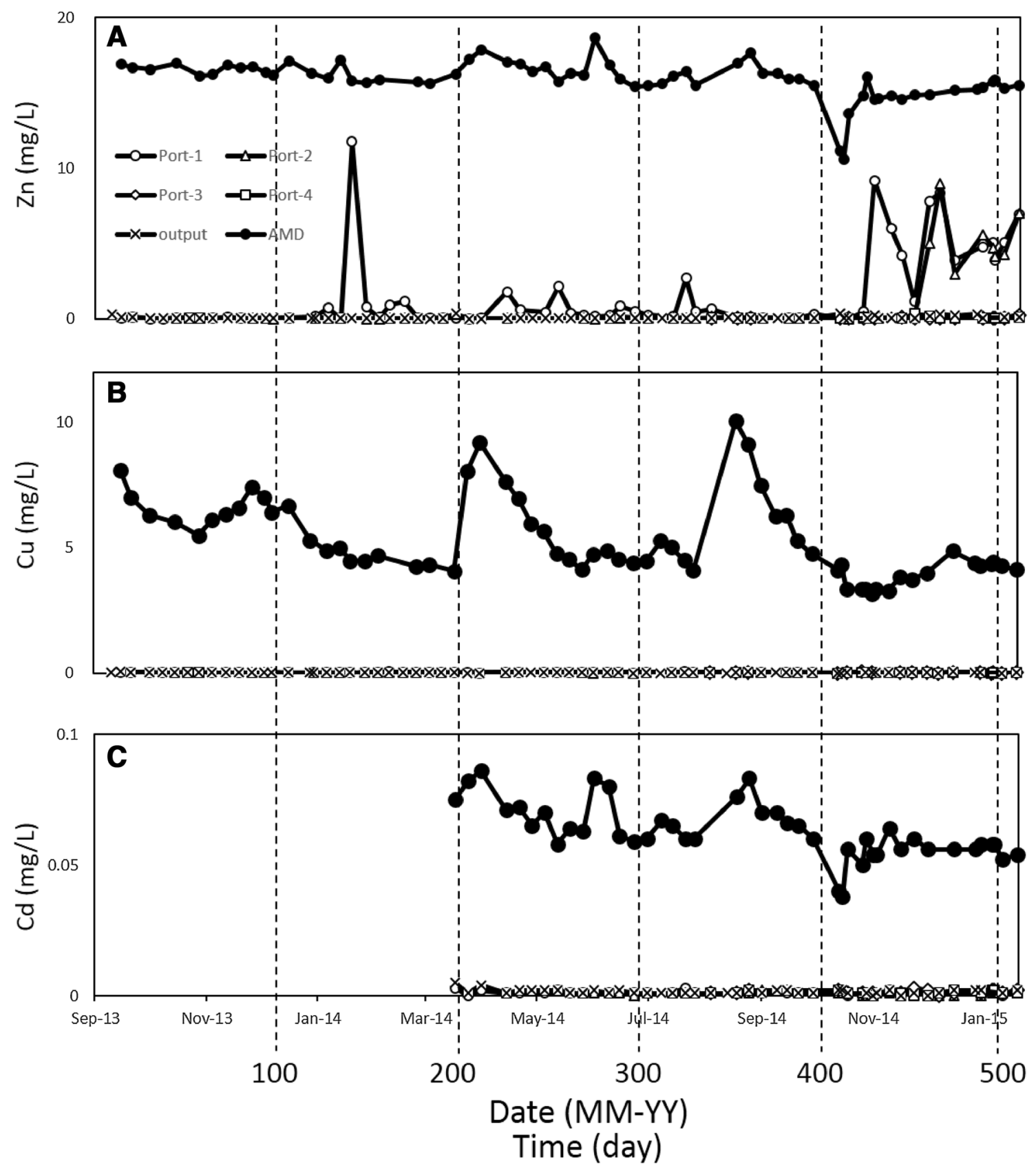

Fig. 5 Variations in metal removal during AMD-impacted water treatment using the sulfate-reducing bioreactor from September 2013 to January, 2015. Shown are the concentrations of $\mathrm{Zn}(\mathbf{a}), \mathrm{Cu}(\mathbf{b})$, and $\mathrm{Cd}(\mathbf{c})$. Concentration values show the total concentration of the sol-

portion of the reactor, i.e. the sulfate concentrations of water sampled from Port 1 were about $25-50 \%$ of those at the inlet port. The sulfate ion concentrations at Port 1 were initially around $230 \mathrm{mg} / \mathrm{L}$ (September to mid-November 2013), but rose above $250 \mathrm{mg} / \mathrm{L}$ between mid-November 2013 and April 2014. After May 2014, the sulfate ion concentrations decreased to around $150 \mathrm{mg} / \mathrm{L}$, but they increased again to above $250 \mathrm{mg} / \mathrm{L}$ at the beginning of October 2014 (Fig. 4a). uble ion in water and the precipitated ion in suspended precipitates. Symbols: open circle Port 1, open triangle Port 2, open diamond Port 3 , open square Port 4, cross outlet, closed circle AMD

Based on this trend, it appears that the SRB reduced the AMD sulfate ions to sulfide ions using low molecular carbon sources, such as lactate, ethanol, and other organic materials, as electron donors. According to the reaction [1] (Neculita et al. 2007), these low molecular carbon sources (shown as " $\mathrm{CH}_{2} \mathrm{O}$ ") would be generated from the digested rice bran in the reactor during the JOGMEC process.

$$
2 \mathrm{CH}_{2} \mathrm{O}+\mathrm{SO}_{4}{ }^{2-} \rightarrow 2 \mathrm{HCO}_{3}{ }^{-}+\mathrm{H}_{2} \mathrm{~S}
$$


The variations in sulfate ion concentrations were consistent with the observed trend in ORP values at Port 1, where ORP values rose above $-150 \mathrm{mV}$ [ranging from -240 to $-39 \mathrm{mV}$ from mid-November 2013 to April 2014, and from -274 to $+77 \mathrm{mV}$ from October 2014 to January 2015 (Fig. 3c)].

The effluent sulfate concentrations at the outlet port ranged from 80 to $276 \mathrm{mg} / \mathrm{L}$ (Fig. 4a). Sulfate was stable at $\approx 200 \mathrm{mg} / \mathrm{L}$ until April 2014. After that, a drastic decrease in sulfate concentration (to below $100 \mathrm{mg} / \mathrm{L}$ ) was observed during the summer, before the concentration gradually increased (to around $250 \mathrm{mg} / \mathrm{L}$ ) until mid-October 2014. This is consistent with the fact that the highest ORP values at the outlet port were measured from October 2014 to January 2015 ( -291 to $-84 \mathrm{mV}$; Fig. 3c). The highest sulfate ion reduction rate $(77.8 \%)$ was observed in September 2014, whereas the lowest (0\%) was observed in January 2015.

Figure $4 \mathrm{~b}$ shows the sulfide ion concentrations of sampled waters at Ports 1-4 of the bioreactor. Sulfide ion concentrations increased at the lower port locations. From May 2014 to September 2014, when sulfate-reducing activity was relatively high, the sulfide ion concentrations of the water sampled at Port 4 ranged from 19 to $57 \mathrm{mg} / \mathrm{L}$ (Fig. 4b). By contrast, when the sulfate-reducing activity was relatively low, the sulfide concentrations were $0-14 \mathrm{mg} / \mathrm{L}$. In Fig. 4, the relationship between changes in (a) and (b) is consistent with sulfate reduction causing sulfide ion generation. According to the reaction given in Formula [2] (Neculita et al. 2007), the sulfide ion in solution is available to precipitate metals (shown as "M" in Formula [2]).

$\mathrm{H}_{2} \mathrm{~S}+\mathrm{M}^{2+} \rightarrow \mathrm{MS} \downarrow+2 \mathrm{H}^{+}$

As such, metal sulfides are immobilized within the reactor; thus, metal removal from the AMD is expected.

\section{Metal Removal}

Before treatment in the bioreactor, the iron concentration in the AMD was reduced to $<5 \mathrm{mg} / \mathrm{L}$ by an iron-oxidation reactor (initial average: $40 \mathrm{mg} / \mathrm{L}$ ). This pretreated water was fed into the sulfate-reducing bioreactor. Metal ( $\mathrm{Zn}, \mathrm{Cu}$, and $\mathrm{Cd})$ removal efficiencies by the bioreactor were generally high (Fig. 5).

From September 2013 to September 2014, most of the $\mathrm{Zn}$ was removed in the upper portion of the bioreactor. Removal rates of $\mathrm{Zn}$ at Ports 1 and 2 were 83.6-100\% (except on sampling day 141; Fig. 5a). However, Zn concentrations became unstable and increased after November 2014. A potential reason for this phenomenon is the decrease in sulfate-reducing activity at the lower temperatures observed during winter. However, considering that the $\mathrm{Zn}$ removal rate was relatively stable during the first winter (2013-2014), the depletion of rice bran during continuous operation throughout the year [leading to a lack of organic substrates for SRB in the second winter (2014-2015)] might have caused the decreased sulfate-reducing activity. This hypothesis is supported by the higher ORP values observed in the second winter than in the first winter (Fig. 3c). By contrast, at Port 4, Zn concentrations of $<0.33 \mathrm{mg} / \mathrm{L}$ were observed throughout the year. These values were below Japan's national effluent standard for Zn (2 mg/L).

The bioreactor was also effective at $\mathrm{Cu}$ removal. The $\mathrm{Cu}$ concentrations at the inlet port ranged from 3.2 to $10.0 \mathrm{mg} / \mathrm{L}$ (Fig. 5b), whereas effluent concentrations were $<0.08 \mathrm{mg} / \mathrm{L}$. Therefore, $\mathrm{Cu}$ removal rates were $99.1-100 \%$. In addition, although Cd measurements were only started in March 2014, the trend in $\mathrm{Cd}$ removal by the bioreactor was observed to be similar to that of $\mathrm{Cu}$ (Fig. 5c). The results showed 93.3-100\% removal rates and the effluent concentrations were $<0.005 \mathrm{mg} / \mathrm{L}$. The trends in metal removal in the bioreactor corresponded with sulfate ion removal and sulfide ion generation, strongly suggesting metal sulfide precipitation.

\section{Analysis of SRB Populations within the Bioreactor in January}

To provide low molecular organic substrates, e.g. lactic acid, acetic acid, formic acid, and ethanol, to SRB, efficient digestion and fermentation of polysaccharides in the rice bran by environmental microorganisms is necessary. SRB and fermentative bacteria are believed to construct ecosystems in the bioreactor, but little is known about the SRB communities that treat AMD. The recent development of high-throughput DNA sequencing technologies, especially the Illumina platform for 16S rRNA amplicon sequencing, enables analysis of the complicated microbial community structures in the environment (Hori et al. 2015; Sato et al. 2016); thus, SRB communities in the bioreactor could be monitored at a fine scale.

The seasonal changes in all measured physicochemical parameters suggested that microbial activity in the bioreactor was generally higher in summer than in winter. Therefore, in the summer, the higher efficiency of metal removal and sulfate ion reduction was likely achieved due to both higher microbial degradation of the rice bran and greater proliferation of the SRB population, even in the upper portion of the reactor (around Port 1).

On the other hand, with the onset of winter, a gradual decrease in sulfate-reducing activity within the bioreactor, followed by an increase in ORP values, was observed (Fig. 4a). The lowest sulfate ion reduction rates were observed in January, when the laboratory temperature was low (Fig. 3a). To better understand SRB populations during the cold season, the most dominant SRB genus within the bioreactor (in samples from Ports 1 and 4) was investigated in January 2015 (506 days) by Illumina sequencing 
of $16 \mathrm{~S}$ rRNA genes. The total numbers of $16 \mathrm{~S}$ rRNA gene sequences obtained from Ports 1 and 4 were 128,527 and 123,927 , respectively; SRB were found to dominate, comprising 40.5 and $10.4 \%$ of all sequences, respectively. This result indicated that the SRB population was greater at Port 1 than it was at Port 4. Of the SRB population at both sampling ports, Desulfatirhabdium butyrativorans-related species belonging to a novel lineage within Deltaproteobacteria (Balk et al. 2008) dominated, accounting for 47.7 and 39.4\% of the total SRB communities in Ports 1 and 4, respectively (19.3 and $4.1 \%$ of the total number of $16 \mathrm{~S}$ rRNA gene sequences, respectively). The phylogenetic affiliations of Deltaproteobacteria-related SRB found at Ports 1 and 4 are presented in Supplemental Fig. 1. The presence of nutritionally versatile SRB affiliated with Deltaproteobacteria, as well as another type of SRB affiliated with Firmicutes (data not shown), was observed within the bioreactor, suggesting that the digestion and fermentation of rice bran resulted in a diverse range of organic products.

\section{Conclusion}

A laboratory-scale sulfate-reducing bioreactor containing rice bran and husk (both agricultural wastes) was successfully operated to treat AMD for over a year. Efficient metal removal was observed, with concentrations at the outlet port of $<0.33 \mathrm{mg} / \mathrm{L} \mathrm{Zn},<0.08 \mathrm{mg} / \mathrm{L} \mathrm{Cu}$, and $<0.005 \mathrm{mg} / \mathrm{L}$ $\mathrm{Cd}$ during operation. These values more than meet Japan's national effluent standards. Metabolically diverse SRB populations within the bioreactor in January were identified by Illumina sequencing. In particular, it was revealed that Desulfatirhabdium butyrativorans-related species belonging to a lineage within Deltaproteobacteria dominated (39-48\% of the total SRB population) within the bioreactor. Considering that a sulfidogenic condition was maintained throughout the operation of the bioreactor, SRB could likely use simple carbon substrates derived from the microbial digestion and fermentation of the rice bran. Therefore, the JOGMEC treatment process is potentially an effective metal removal process for AMD.

Open Access This article is distributed under the terms of the Creative Commons Attribution 4.0 International License (http://creativecommons.org/licenses/by/4.0/), which permits unrestricted use, distribution, and reproduction in any medium, provided you give appropriate credit to the original author(s) and the source, provide a link to the Creative Commons license, and indicate if changes were made.

\section{References}

Balk M, Altinbas M, Rijpstra WI, Sinninghe Damsté JS, Stams AJ (2008) Desulfatirhabdium butyrativorans gen. nov., sp. nov., a butyrate-oxidizing, sulfate-reducing bacterium isolated from an anaerobic bioreactor. Int J Syst Evol Microbiol 58:110-115

Caporaso JG, Kuczynski J, Stombaugh J, Bittinger K, Bushman FD, Costello EK, Fierer N, Pena AG, Goodrich JK, Gordon JI, Huttley GA, Kelley ST, Knights D, Koenig JE, Ley RE, Lozupone CA, McDonald D, Muegge BD, Pirrung M, Reeder J, Sevinsky JR, Turnbaugh PJ, Walters WA, Widmann J, Yatsunenko T, Zaneveld J, Knight R (2010) QIIME allows analysis of high-throughput community sequencing data. Nat Methods 7(5):335-336

Chang IS, Shin PK, Kim BH (2000) Biological treatment of acid mine drainage under sulfate-reducing conditions with solid waste materials as substrate. Water Res 34(4):1269-1277

Colmer AR, Hinkle ME (1947) The role of microorganisms in acid mine drainage: a preliminary report. Science 106(2751):253-256

DeSantis TZ, Hugenholtz P, Larsen N, Rojas M, Brodie EL, Keller K, Huber T, Dalevi D, Hu P, Andersen GL (2006) Greengenes, a chimera-checked 16S rRNA gene database and workbench compatible with ARB. Appl Environ Microbiol 72(7):5069-5072

Gibert O, de Pablo J, Cortina JL, Ayora C (2004) Chemical characterization of natural organic substrates for biological mitigation of acid mine drainage. Water Res 38(19):4186-4196

Gusek J, Wildeman T, Miller A, Fricke J (1998) The challenges of designing, permitting and building a 1,200 gpm passive bioreactor for metal mine drainage West Fork mine, Missouri. In: Proceedings of 15th Annual Meeting of the American Soc for Surface Mining and Reclamation (ASSMR), St. Louis, MO, pp. 203-212

Hamai T, Kodera T, Kobayashi M, Masuda N, Sakata T (2016) The sequential tests about passive treatment for acid mine drainage using sulfate reducing bacteria (In Japanese). J MMIJ 132(11):175-181

Hiibel SR, Pereyra LP, Riquelme Breazeal MV, Reisman DJ, Reardon KF, Pruden A (2011) Effect of organic substrate on the microbial community structure in pilot-scale sulfate-reducing biochemical reactors treating mine drainage. Environ Eng Sci 28(8):563-571

Hori T, Aoyagi T, Itoh H, Narihiro T, Oikawa A, Suzuki K, Ogata A, Friedrich MW, Conrad R, Kamagata Y (2015) Isolation of microorganisms involved in reduction of crystalline iron(III) oxides in natural environments. Front Microbiol 6:386. doi:10.3389/ fmicb.2015.00386/full

Kolmert Å, Johnson DB (2001) Remediation of acidic waste waters using immobilised, acidophilic sulfate-reducing bacteria. J Chem Technol Biotechnol 76(8):836-843

Kumar S, Stecher G, Tamura K (2016) MEGA7: Molecular evolutionary genetics analysis, version 7.0 for bigger datasets. Mol Biol Evol 33(7):1870-1874

McCullough CD, Lund MA (2011) Bioremediation of acidic and metalliferous drainage (ADM) through organic carbon amendment by municipal sewage and green waste. J Environ Manage 92:2419-2426

Mine Safety and Explosives Control Division, Commerce, Distribution and Industrial Safety Policy Group (2013) Act on special measures for pollution caused by the metal mining industry, etc. Policy Index of Ministry of Economy, Trade and Industry, Japan

Nairn RW, LaBar JA, Strevett KA, Strosnider WH, Morris D, Neely CA, Garrido A, Santamaria B, Oxenford L, Kauk K, Carter S, Furneaux B (2010) A large, multi-cell, ecologically engineered passive treatment system for ferruginous lead-zinc mine waters. In: Proceeding of international mine water association annual meeting, pp 21-24

Neculita CM, Zagury GJ, Bussiere B (2007) Passive treatment of acid mine drainage in bioreactors using sulfate-reducing bacteria: critical review and research needs. J Environ Qual 36:1-16

Neculita CM, Yim GJ, Lee G, Ji SW, Jung JW, Park HS (2011) Comparative effectiveness of mixed organic substrates to mushroom compost for treatment of mine drainage in passive bioreactors. Chemosphere 83:76-82 
Postgate JR (1984) The sulphate reducing bacteria, second edit. Cambridge University Press, Cambridge

Prasad D, Wai M, Berube P, Henry JG (1999) Evaluating substrates in the treatment of acid mine drainage. Environ Technol 20:449-459

Price WA, Errington JC (1998) Guidelines for metal leaching and acid rock drainage at minesites in British Columbia. Ministry of Energy and Mines, British Columbia

Rakotonimaro TV, Neculita CM, Bussière B, Benzaazoua M, Zagury GJ (2016) Recovery and reuse of sludge from active and passive treatment of mine drainage-impacted waters: a review. Environ Sci Pollut Res 24(1):73-91

Saitou N, Nei M (1987) The neighbor-joining method: a new method for reconstructing phylogenetic trees. Mol Biol Evol 4(4):406-425

Sato Y, Hori T, Navarro RR, Habe H, Ogata A (2016) Functional maintenance and structural flexibility of microbial communities perturbed by simulated intense rainfall in a pilot-scale membrane bioreactor. Appl Microbiol Biotechnol 100(14):6447-6456

Tamura K, Nei M, Kumar S (2004) Prospects for inferring very large phylogenies by using the neighbor-joining method. Proc Natl Acad Sci 101(30):11030-11035

The Interstate Technology \& Regulatory Council (ITRC) BiochemicalReactors for Mining-Influenced Waste Team (2013) Biochemical reactors for mining-influenced water. http://itrcweb.org/bcr-1/

Zagury GJ, Kulnieks VJ, Neculia CM (2006) Characterization and reactivity assessment of organic substrates for sulfate-reducing bacteria in acid mine drainage treatment. Chemosphere 64:944-954

Zhang M, Wang H (2014) Organic wastes as carbon sources to promote sulfate reducing bacterial activity for biological remediation of acid mine drainage. Miner Eng 69:81-90 